\title{
Adölesanların Kilo Yönetiminde 5210 Beslenme Yönetimi Programının Etkisi
}

\author{
Emine EKİCi' ${ }^{1} \oplus$, Ayşe YILDIZ²® \\ ${ }^{1}$ Üsküdar Üniversitesi Sağlık Bilimleri Fakültesi, Hemşirelik Bölümü, İstanbul \\ ${ }^{2}$ Biruni Üniversitesi Sağlık Bilimleri Fakültesi, Hemşirelik Bölümü, İstanbul
}

Bu makaleye yapılacak atıf: Ekici E, Yıldız A. Adölesanların Kilo Yönetiminde 5210 Beslenme Yönetimi Programının Etkisi Turk J Diab Obes 2018 ;2:73-85.

\begin{abstract}
ÖZET
Amaç: Araştırmanın amacı öğrencilerden oluşan deney grubuna (11-12 yaş grubu kilolu ve obez) uygulanan 5210 kilo yönetimi programının öğrencilerin Beden Kitle İndeksi (BKİ), bel çevresi, beslenme - egzersiz tutum ve davranışları üzerindeki etkisini incelemektir.

Gereç ve Yöntemler: Bu çalışma yarı deneysel olarak yapıldı. Araştırma örneklemini İstanbul'da aynı ilçede iki özel okulda öğrenim gören 34 kontrol grubu ve 31 deney grubu olmak üzere toplam 65 adölesan oluşturdu. Araştırmanın verileri Antropometrik Ölçüm Formu, Öğrenci Sağlıklı Yaşam Anketi, Aile Bilgi Formu, Beslenme Egzersiz Tutum Ölçeği (BETÖ) ve Beslenme Egzersiz Davranış Ölçeği (BEDÖ) kullanılarak toplandı. Veriler uygulama öncesinde, uygulama sonrası 6. ayda ve 9. ayda olmak üzere toplam üç ölçümde toplandı. Çalışmanın analizinde tanımlayıcı istatistiksel testler, Student's t test, Mann Whitney U, tekrarlı ölçümlerde varyans analizi, düzeltilmiş Wilcoxon Signed-Ranks test ve Pearson Ki-Kare test kullanıldı.

Bulgular: Deney ve kontrol grupları arasında ölçümlerde BKİ dağılımları ve ortalamaları bakımından istatistiksel olarak anlamlı farklılık saptanmamasına karşın ( $>0$,05) deney grubunda, 1.ölçüm (başlangıç) BKİ dağılımlarına göre 2.ölçüm (6.ay) ve 3. ölçümde (9.ay) gözlenen değişimin istatistiksel olarak anlamlı olduğu saptandı $(\mathrm{p}<0,05)$. İkinci ve üçüncü ölçüm BKİ değeri normal olan adölesanlarda birinci ölçüme göre artış ( 9 kişi) bulundu. Deney grubundaki adölesanların başlangıç ölçümlerine göre 9 . ay ölçümlerinde BKİ ortalamalarındaki değişimin, istatistiksel olarak anlamlı olmamakla birlikte dikkat çekici düzeyde düşük olduğu saptandı (p>0,05). Buna göre kontrol grubu kilo almaya devam ederken deney grubunun normal gelişimlerini sürdürdüğü ve kontrol grubuna göre daha az kilo aldıkları söylenebilir. Deney grubunun girişim öncesi BETÖ ölçeği puan ortalaması 47,77 $\pm 6,25,2$. ölçüm 47,16 $\pm 7,98,3$. ölçüm $48,52 \pm 7,48$ olarak bulundu.

Sonuç: 5210 kilo yönetimi programının adölesanların BETÖ, BEDÖ ve alt ölçekleri puan ortalamalarını etkilemediği bulundu. Bu sonuçlar doğrultusunda 5210 programının çoklu girişimler eklenip süresi arttırıldığında daha etkili olacağı düşünüldü. 10-12 yaş grubuna yönelik 5210 mesajlarını içeren 12 saatlik bir eğitim programı geliştirildi. Eğitime ilişkin görsel metaryaller ve sunumlar hazırlandı, seansların amaç ve hedeflerini içeren içerik kitapçı̆̆ı oluşturuldu. Bu program ve materyaller daha geniş bir örneklemde kullanılabilir.
\end{abstract}

Anahtar Sözcükler: Adölesan, 5210, Beslenme, Fiziksel aktivite

\section{Effects of 5210 Nutrition Management Program in Weight Management of Adolescents}

\begin{abstract}
Aim: The purpose of the study is to examine the impact of 5210 weight management program executed to students (11-12 year olds are overweight and obese students) on attitudes and behaviors towards Body Mass Index (BMI), waist circumference on the nutritional habits. The research was conducted in semi-experimental semi-empirical model.
\end{abstract}

* Bu çalışma 1. Uluslararası 2. Ulusal Halk Sağlığı Hemşireliği Kongresi’nde poster olarak sunulmuştur. (23-26 Nisan 2018)

DOI: $10.25048 /$ tjdo.2018.175 
Material and Methods: Sample of research is compose of 65 teenagers of which 34 control group (16 obese and 18 overweight) and 31 controlgroup (14 obeseand 17 overweight) in 2 separate schools in the same district of Istanbul. Experimental/Control groups had been formed by choosing the obese and overweight students in the both schools. The data of research had been collected via Anthropometric Measurement Form, Survey on Student Healthy Life, Family Information Form, Scale of Attitudetowards Nutritionand Fitness (SANFSBNF), and Scale of Behavior of Nutritionand Fitness (BEDÖ). Data was measured three times of which before execution of program and 6 and 9 months after execution of education.

Results: Inspite of it is determined that there is significant difference in the BMI distributions and BMI averages of first measurement, second measurement and third measurement in experimental and control groups ( $p>0,05)$, the change in the BKİ averages is statistically significant in from 2 nd measurement of BMI averages compared with initial measurement in experimental groups to 3rd measurement $(\mathrm{p}<0,05)$. There are increases in the number of adolescents who have normal BMI valuefrom 2nd measureto 3rd measure. The change in BMI averages from 9th month measure to initial measure in experimental group is not statistically different with the one measured in control group $(\mathrm{p}>0,05)$. Control group keepgo on get weight while experimental group was growing up normally and get lower weight compared with control group. Averages of SANF scale are calculated as 47,77 $\pm 6,25$ at the initiation of program 47,16 $\pm 7,98$ at the second measure and 48,52 \pm 7,48 at the third measure. 5210 weight management is not effective on both SANF averages, SBNF averages and their subscales. A training program of 12 hours totaling 2 to 6 weeks a week, including.

Conclusion: 5210 messages for the 10-12 age group, was developed. Educational visual materials and presentations were created and an educational content booklet containing course content plans, goals and objectives of the sessions was created. These programs and materials can be used in a wider sample. Furter study is needed to 5210 program will be effective via multiple additives and longer term durations.

Key Words: Adolescent, 5210, Nutrition, Physicalactivity

\section{GIiRIŞ}

Obezite, günümüzde yanlış beslenme alışkanlıklarının artmasıyla birlikte adölesanlarda sık görülen bir problemdir ve adölesanların 2/3'ünde yetişkin yaşlarda devam etmektedir (1-6). Dünya Sağlık Örgütü (WHO) Avrupa Bölge Ofisi'nin 2011 raporunda obezite epidemisinin dünyanın en önemli halk sağlığı müdahalelerinden biri olduğu ve özellikle çocuklar ve gençler için alarm verici düzeyde ilerlediğine dikkat çekilmektedir. Söz konusu rapora göre Türkiye'nin de içinde bulunduğu WHO Avrupa Bölgesi'nde obezite prevalansı son 20 yıl içinde üç kat artmıştır.

Çocuk yaşta aşırı kilolu olma durumu daha çok gelişmiş ülkelerde görülmekle birlikte az-orta gelir seviyesindeki ülkelerde daha hızlı artış göstermektedir (7-9). Büyüme ve gelişmenin hızlandığı, öğrenme ve kavrama işlevlerinin önem kazandığı çocukluk ve adölesan dönemde beslenmenin önemi daha da artmaktadır (10). Hastalık yükü hesaplamasında demir eksikliğinden kaynaklanan anemi DALY (Disability Adjusted Life Year) adölesanlarda üçüncü sıradadır (11). Bilişsel gelişim açısından bu dönemdeki yetersiz ve dengesiz beslenme; öğrenme kapasitesinde azalma, yoğunlaşma güçlügü ve okul performansında düşme gibi sonuçları vardır.

Diğer taraftan obezite, kalp damar hastalıkları, kanser ve diyabet gibi birçok kronik hastalığın zeminini dengesiz beslenme ve yetersiz fiziksel aktivite hazırlamaktadır. Dünya genelinde her dört adölesandan sadece biri günde bir saat orta düzeyde fiziksel aktivite yapmaktadır (11). $\mathrm{Bu}$ dönemde kazanılan beslenme ve egzersiz alışkanlıkları yetişkin döneme de yansıyacağından adölesanların beslenme durumlarının doğru bir şekilde değerlendirilmesi ve izlenmesi son derece önemlidir $(11,12)$.

2009-2010 döneminde Avrupa Birliğine üye 39 ülkede 11, 13 ve 15 yaş grubunda yapılan Okul Çağı Çocuklarında Sağlık Davranışı (The Health Behaviour in School-aged Children (HBSC)) araştırmasındaki beyana bağlı boy uzunluğu ve vücut ağırlığı verileri değerlendirildiğinde 11 yaş grubunda $\% 15$ 'inin, 13 yaş grubunda \%14'ünün ve 15 yaş grubunda ise \%14'ünün kilolu ve obez olduğu bildirilmiştir (13).

Amerika Birleşik Devletleri Ulusal Beslenme ve Sağlık Araştırması (NHANES) 2009-2010 yılı sonuçlarına göre yaklaşık 12,5 milyon çocuk ve adölesan $(\% 16,9)$ obezdir [kızlarda \%15 ve erkeklerde \%18,6] (14).

Ülkemizde Sağlık Bakanlığı’nın yaptığı “Okul Çağı Çocukların Büyümesinin İzlenmesi (6-10 yaş)” projesine göre çocukların \% 6,5'i obez ve \%14,3'ü fazla kilolu bulunmuştur (15). Türkiye Beslenme ve Sağlık Araştırması (TBSA 2010) çalışmasında BKİ değerlerine göre obezitenin en fazla görüldüğü bölgeler Doğu Marmara $(\% 12,5)$, Ege $(\% 11,4)$, Akdeniz $(\% 11,4)$ [İstanbul $(\% 10,8)]$. 6-18 yaş grubunda fazla kiloluluk tüm bölgelerde $\% 8,8$ (Ege) ile \%24,6 (İstanbul) arasında bir dağılım göstermekte ve bölgesel olarak farklılık yaratmamaktadır (16). Bu çocukların adölesan döneme de kilolu gireceklerini düşündügümüzde bu durumla mücadele edilmelidir.

Amerikan Pediatri Akademisi 2007 yılında çocuk ve adölesanlarda obezite yönetimine ilişkin 5210 mesajlarını yayınlamıştır. Buna göre günde beş porsiyon sebze ve 
meyve tüketimi ve meyve suyunun günde $100 \mathrm{ml}$ ile sınırlandırılması, televizyon ve bilgisayar karşısında iki saatten az zaman geçirme, günde en az bir saat orta düzeyde fiziksel aktivite, şekerli içecek yerine su ve günde üç kez bir porsiyon süt tüketimi önerilmektedir $(17,18)$. Amerika'nın Maine eyaletinde uygulanan 5210 kampanyası sonucunda çocukluk çağı obezite oranının \%1,5 azaldığı tespit edilmiştir $(19,20)$.

Obezitenin önlenmesi, tedavisi ve bireyin bakımı multidisipliner işbirliği gerektiren bir süreçtir $(21,22)$. $\mathrm{Bu}$ sürecin bakım sorumluluğu hemşireye aittir. Okullar, planlanan girişimlerin sunulması, sağlı̆̆ın geliştirilmesi ve sürdürülmesi için uygun yerler olduğundan çocukluk çağı obezliğini önlemek ve azaltmak için okullardan yararlanılabilir $(23,24)$.

5210 kilo yönetimi programı uygulanan araştırmanın amacı deney grubundaki 11-12 yaş arası kilolu ve obez öğrencilere uygulanan BKİ, bel çevresi, beslenme - egzersiz tutum ve davranıșları üzerindeki etkisini incelemektir.

\section{GEREÇ ve YÖNTEMLER}

Deney ve kontrol grupları birbirine benzer iki okuldan seçilmiş ve çalışmanın yapısı gereği randomizasyon sağlanamamıştır. Çalışmamız, İstanbul Kartal ve Yakacık Kampüslerinde, ortaokul kısmında öğrenim gören, velisinin yazılı onayı ile araştırmaya katılmayı kabul eden, 85 ve üzeri persantilde, kilolu ve obez öğrencilerin alındığı yarıdeneysel bir araştırmadır.

Çalışmada hangi okulun deney grubu olacağ kura yöntemi ile belirlenmiş olup, Yakacık'taki öğrenciler deney grubunu ve Kartaldaki öğrenciler kontrol grubunu oluşturdu. Özellikle 6 ve 7. (10-12 yaş) sınıftaki öğrencilerin seçilme nedenleri bilişsel açıdan soyut düşünme ve anlama becerilerinin arttığı ve sağlıksız beslenmenin de içinde bulunduğu risk alma davranışlarının ortaya çıtığı yaş döneminde (erken adölesan dönem) bulunmalarıydı (25).

Çalışmada örnek büyüklügünü belirlemek için güç analizi yapıldı. "Adölesanların Kilo Yönetiminde 5210 Beslenme Yönetimi Programı" ile adölesanların beslenme ve egzersiz tutumlarında program öncesine göre, değişimde öngörülen ortalama 6,0 puan farkın $\pm 7,2$ standart sapmada anlaml bulmak için Tip I hata $\% 5$, Tip II hata $\% 20$ kabul edildi ( $\alpha=$ $0,05,1-\beta=0,80$ ) ve minimal örneklem büyüklüğü 48 (her bir grup için $n=24$ ) olarak bulundu.

Deney ve kontrol grubundaki tüm 6 ve 7. sinıflarda kilolu ve obez öğrenciler belirlendikten sonra örnekleme alındı. Çalışmaya katılan iki okulun 6 ve 7 sinıf öğrencileri deney ve kontrol grubu şeklinde ayrıldı (87 deney ve 77 kontrol). Deney grubunun ailelerine $2 \mathrm{kez}$ kontrol grubu ailelerine 1 kez olmak üzere okul yöneticilerinin desteği ile e-posta ve onam formu gönderildi ve araştırmaya katılmayı kabul edenlerden deney (14'ü obez ve 17'si hafif kilolu olmak üzere 31 öğrenci) ve kontrol (16’sı obez ve 18 'i hafif kilolu olmak üzere 34 öğrenci) grubu oluşturuldu.

\section{Veri Toplama}

Araştırma verileri beş farklı form ile toplandı. Antropometrik Ölçüm Formu, Öğrenci Sağlıklı Yaşam Anketi ve Aile Bilgi Formu literatürden yararlanılarak araştırmacı tarafından oluşturuldu.

\section{Formlar;}

Antropometrik Ölçüm Formu: 6,7. sınıf tüm öğrencilere uyguland

Aile Bilgi Formu: Deneyve kontrol grubundakiöğrencilerin anne ve babalarının sosyodemografik özellikleri, beslenme, egzersiz ve TV izleme durumları ve obezite ile ilgili bireysel ve ailesel risk faktörleri ile ilgili soruları içeren anket formu annelere uyguland.

Beslenme Egzersiz Tutum Ölçeği (BETÖ): Öğrencilerin beslenme ile ilgili tutumların belirlemek amacı ile Yurt, (2008) tarafından geliştirilen bu ölçek beşli likert tipinde (1: hiçbir zaman, 5: daima) 13 maddeden oluşmaktadır. Ölçekte yer alan tüm maddeler olumlu ifade içermekte olup ters kodlanan soru bulunmamaktadır. Ölçek toplam puanı 12 ile 73 puan arasında değişmekte olup, ölçekten alınan toplam puanın yüksek olması, beslenme ve egzersiz davranışları arasında olumlu bir tutumun olduğunu göstermektedir (26).

Beslenme Egzersiz Davranış Ölçeği (BEDÖ): Öğrencilerin beslenme ile ilgili davranışlarını belirlemek amacı ile Yurt, (2008) tarafından geliştirilen bu ölçek beşli likert tipinde (1: Beni hiç tanımlamıyor, 5: Beni tamamen tanımlyyor), 45 madde ve 4 alt boyuttan oluşmaktadır. Ölçek yorumu alt boyutlardan alınan puanlara göre yapılmakta olup, ölçekte yer alan $[7,8,9,10,11,12,14,15,17,18,20,22,30,31,32$, $34,35,36,37,38,39,42,43$ numaralı maddeler] ters yönde kodlanmaktadır. Ölçek alt boyutları;

- Faktör 1 (Psikolojik / Bağımlı Yeme Davranışı); 11 maddeden oluşmaktadır $[7,8,10,20,22,34,35,36,37$, 38, 39 maddeler]. Bu alt boyuttan alınabilecek puan 11 ile 55 arasındadır. Alınan puanın yüksek olması psikolojik yeme davranışının yüksek olduğunu gösterir.

- Faktör 2 (Sağlıklı Beslenme-Egzersiz Davranışı); 14 maddeden oluşmaktadır $[13,16,19,23,24,25,26,27$, $28,33,40,41,44$ maddeler]. Bu alt boyuttan alınabilecek puan 14 ile 70 arasındadır. Alınan puanın yüksek olması sağlıklı beslenme-egzersiz davranışının yüksek olduğunu gösterir. 
- Faktör 3 (Sağlıksız Beslenme-Egzersiz Davranışı); 14 maddeden oluşmaktadır $[9,11,12,14,15,17,18,21,29$, 30, 31,32, 42, 43 maddeler]. Bu alt boyuttan alınabilecek puan 14 ile 70 arasındadır. Alınan puanın yüksek olması sağlıksız beslenme-egzersiz davranışının yüksek olduğunu gösterir.

- Faktör 4 (Öğün Düzeni); 6 maddeden oluşmaktadır [1, 2, 3, 4, 5, 6 maddeler]. Bu alt boyuttan alınabilecek puan 6 ile 30 arasında değişmektedir. Alınan puanın yüksek olması öğün düzeninin iyi olduğunu gösterir. Ölçekler 12-14 yaşları arasındaki adölesanlarda geliştirilmiştir.

Beden Kitle İndeksi değerlendirmesi için Neyzi ve ark. (2008) tarafından geliştirilen, yaş ve cinsiyeti dikkate alan "Türk çocuklarında vücut ağırlığı, boy uzunluğu ve Beden Kitle İndeksi referans değerleri” kullanıldı. BKİ'ye göre çocuklarda obezite riskinin değerlendirilmesinde WHO'nun çocuklar için BKİ kesme değerleri kullanıldı $(27,28)$. BKİ değerlerine aşağıdaki değerlendirmeye göre persentil değerleri 85 ve üzeri çocuklar araştırmaya alındı.

BKİ Değerlendirme:

- Zayıf/ Kisa: $<5$. persentil

- Normal: 5. - 85. persentiller arasi

- Kilolu/Uzun boy: 85.- 95. persentiller aras1

- Şişman (obez)/Çok uzun: $\geq 95$. persentil

Araştırmanın akış şeması Şekil 1'de gösterilmektedir.

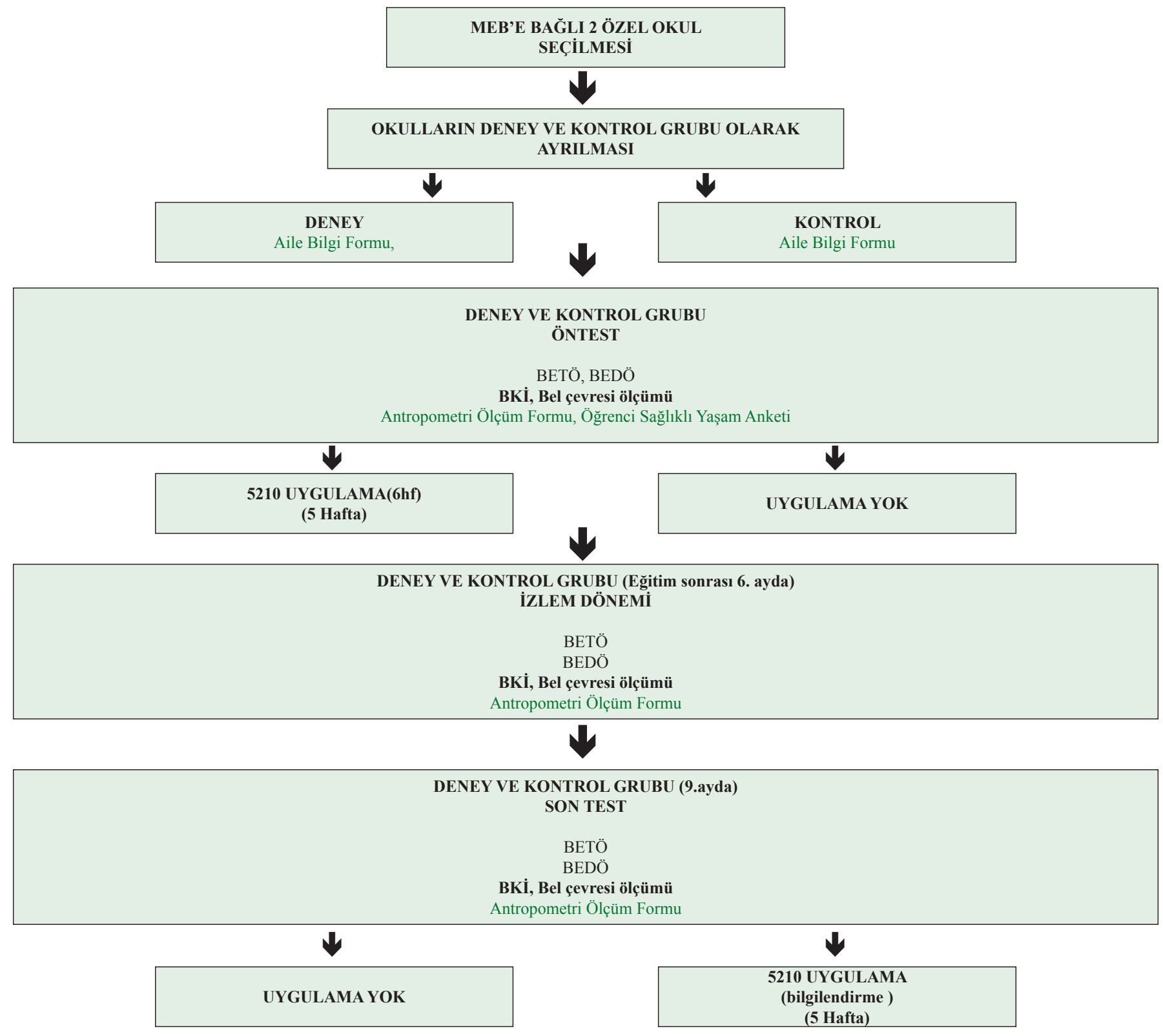

Şekil 1: Araştırma Akış Şeması 
Etik

Araştırma için, Milli Eğitim Müdürlügüu’nden yazılı izin, Haliç Üniversitesi Etik Kurulu'ndan 30.102013 tarih ve 59 sayılı etik onayı, 5210 stratejileri için www.letsgo.org internet sitesi yöneticilerinden 5210 materyallerinin kullanımına ilişkin e-posta yolu ile izin, çalışmada kullanılacak eğitim programı için Palo Alto Medical Foundation'un adölesan okul beslenme programı sorumlusu Jeremy Loader'dan izin, kullanılan ölçekler için Seher YURT'dan izin, çalışmaya başlamadan önce deney ve kontrol grubundaki her öğrencinin velisinden yazılı izin ve öğrencilerden de sözlü onam alındı.

\section{Veri Analizi}

İstatistiksel analizler için NCSS (Number Cruncher Statistical System) 2007 programı kullanıldı. Çalışma verileri değerlendirilirken tanımlayıcı istatistiksel metotların (ortalama, standart sapma, medyan, frekans, oran, minimum, maksimum) yanı sıra niceliksel verilerin karşılaştırılmasında normal dağılım gösteren değişkenlerin iki grup karşılaştırmalarında Student's t test, normal dağılım göstermeyen değişkenlerin iki grup karşılaştırmalarında ise Mann Whitney $U$ test kullanıldı. Normal dağılım gösteren değişkenlerin grup içi karşılaştırmalarında Tekrarlı Ölçümlerde Varyans Analizi ve ikili karşılaştırmaların değerlendirmelerinde Düzeltilmiş Bonferroni Test kullanıldı. Normal dağ1lım göstermeyen değişkenlerin grup içi karşılaştırmalarında ise Friedman Test ve ikili karşılaştırmaların değerlendirilmesinde Wilcoxon Signed-Ranks test kullanıldı. Niteliksel verilerin karşılaştırılmasında ise Pearson Ki-Kare test, Fisher's Exact Test ve Fisher-Freeman-Halton Exact Test ve ve Marginal Homogeneity Test kullanıldı. Ölçeklerin iç tutarlılıklarının değerlendirilmesinde Cronbach alfa katsay1sı kullanıldı. Anlamlılık $\mathrm{p}<0,01$ ve $\mathrm{p}<0,05$ düzeylerinde değerlendirildi.

\section{Eğitim Programının İçeriği}

Araştırmada yapılan eğitim programında kullanılan 5210 materyalleri Amerika'da birçok eyalette uygulanan "Let's go" projesi web sitesinden uyarland. Ayrica Palo Alto Medical Foundation'un 10-11 yaş dönemi için geliştirilen adölesan beslenme programı Türkçe 'ye çevrildi. Eğitim programı içeriği hazırlanırken üç uzmandan görüş alınarak gerekli değişiklikler yapıldı. 5210 mesajlarını içeren eğitim programı 9 bölüm toplam 12 ders saatinden oluşmaktadır. Amerikan Pediatri Akademisi adölesanlara yönelik beslenme ve fizik aktivite önerilerini 5210 rakamlarıyla özetlemiştir. Buna göre; 5 ya da daha fazla porsiyon sebze meyve tüketimi, 2 saat ile sınırlı televizyon ve bilgisayar başında zaman geçirme, 1 saat terleyinceye kadar fizik aktivite, 0 şekerli içecek tüketimi önerilmektedir. 5210 mesajlarına ilişkin sağllk eğitim materyalleri geliştirildi ve eğitimlerde kullanıldı.
Eğitimler araştırmacı tarafından okulların tahsis ettiği projeksiyon ve bilgisayar olan konferans salonlarında gerçekleştirildi. Deney grubuna haftada 2 saat 6 hafta olmak üzere toplam 12 saat eğitim gerçekleştirildi. Eğitim sırasında araştırıcı tarafından hazırlanan materyallerin (yiyecek etiketleri, restoran menüleri) yanında Halk Sağlığ Müdürlügü̈nden temin edilen beslenme replikaları, beslenme panosu ve Sağlık Bakanlığı'nın konu ile ilgili broşürleri kullanıldı.Deney grubuna eğitim programı uygulandıktan sonra tekrar testlere kadar geçen sürede facebook üzerinden oluşturulan grupla hatırlatıcı notlar paylaşıldı.

Eğitim programı uygulanmadan önce velilere ve öğretmenlere okulun konferans salonunda iki seans adölesan dönemde obezite ve öğrencilerle yapılacak çalışmalar hakkında toplantılar düzenlendi. Eğitim programı içeriği kitapçık haline getirildi.

Eğitim sonrası deney ve kontrol grubunun 6.ayda ve 9.ayda beslenme ve egzersiz tutum ve davranışları ve BKİ ve bel çevresi ölçümleri değerlendirildi. Eğitim sonrası oluşturulan sosyal ağ ile deney grubuna haftada bir 5210 programı mesajlarına yönelik hatırlatmalar yapıldı.

\section{Geçerlilik ve Güvenilirlik}

Beslenme Egzersiz Tutum ölçeği ve Beslenme Egzersiz Davranış ölçeğini geliştiren araştırmacıdan izin alındı. BETÖ ve BEDÖ ölçekleri ülkemizde geliştirilmiş olup geçerliliği ve güvenilirliği Yurt tarafından 2008 yılında gerçekleştirilmiştir. Ölçeklerin iç tutarlığ 1 Cronbach's Alpha ile değerlendirilmiş olup, BETÖ'nin Alpha Değeri: 0,74, BEDÖ'nin Alpha Değeri: 0,85 olarak bulunmuştur. $\mathrm{Bu}$ çalışmada ise Beslenme-Egzersiz Tutum Ölçeğinin Cronbach alfa iç tutarlılık değerinin 0,712 olduğu saptandı. Beslenme-Egzersiz Davranış Ölçeği alt boyutlarından psikolojik (bağımlı) yeme davranışı için Cronbach alfa değeri 0,831 iken, sağlıklı beslenme-egzersiz davranışı için 0,722 ; sağlıksız beslenme-egzersiz davranışı için 0,574 ; öğün düzeni için ise 0,622 olduğu saptand.

\section{BULGULAR}

\section{Girişim Öncesi Bulgular}

Deney ve kontrol grupları arasında çalışmaya katılanların cinsiyet, anne öğrenim durumu, baba öğrenim durumu, ekonomik durum, yaş, ailedeki birey sayısı ortalaması dağılımları bakımından istatistiksel olarak anlamlı farklılık saptanmadi ( $>>0,05)$ (Tablo 1).

Deney ve kontrol grupları arasında 1. ölçümde elde edilen vücut ağırlıkları, boy uzunlukları, bel çevresi ölçümleri, BKİ değerleri bakımından istatistiksel olarak anlamlı fark saptanmadi ( $>0,05)$ (Tablo 2). 


\section{Girișim Sonrası Bulgular}

Deney ve kontrol grupları arasında 1. ölçüm (başlangıç), 2. ölçüm (6. ay), 3. ölçüm (9. ay) BKİ kesme değerlerine göre istatistiksel olarak anlamlı farklılık saptanmadı $(p>0,05)$ (Tablo 3).

Deney grubunda 1.ölçüm BKİ durum dağılımlarına göre 2 . ölçüm,1. ölçüm BKİ durum dağılımlarına göre 3. ölçüm BKİ durumları dağılımlarında gözlenen değişimin istatistiksel olarak anlamlı olduğu saptandı (p:0,016). 1. ölçüme göre 2 . ve 3. ölçümde BKİ değeri normal olanların oranının arttı̆̆ 1 gözlendi. 2. ölçüm (6. ay) BKİ durum dağılımlarına göre 3. ölçüm (9.ay) BKİ durumları dağılımları arasında istatistiksel olarak anlamlı değişim saptanmadı ( $\mathrm{p}>0,05)$ (Tablo 3 ).
Kontrol grubunda 1. ölçüm BKİ durum dağılımlarına göre 2. ölçüm, 1. ölçüm BKİ durum dağılımlarına göre 3. ölçüm BKİ durumları dağılımlarında gözlenen değişimin istatistiksel olarak anlamlı olduğu saptand $d_{1}$ (p:0,034; p:0,048). 1. ölçüme göre 2. ölçüm ve 3. ölçümde BKİ değeri normal olanların oranının arttığı gözlendi. 2. ölçüm (6. ay) BKİ durum dağılımlarına göre 3. ölçüm (9. ay) BKİ durumları dağılımları arasında istatistiksel olarak anlamlı değişim saptanmadı $(\mathrm{p}>0,05)$ (Tablo 3 ).

5210 Kilo Yönetimi Programının adölesanların beslenme ve fizik aktivite tutum ve davranışları üzerine etkisine ilişkin bulgular

Deney grubu adölesanlarda girişim öncesi BETÖ ölçeği puan ortalaması $47,77 \pm 6,25$ olarak bulundu (Tablo 4 ).

Tablo 1: Deney ve Kontrol Grubu Adölesanların Tanıtıcı Özellikleri ve Karşılaştırılması (N=65).

\begin{tabular}{|c|c|c|c|c|c|c|c|}
\hline \multirow{2}{*}{ Tanıtıcı Özellikler } & \multicolumn{2}{|c|}{ Deney grubu $(n=31)$} & \multicolumn{2}{|c|}{ Kontrol Grubu $(n=34)$} & \multirow{2}{*}{$\chi^{2}$} & \multirow{2}{*}{ sd } & \multirow{2}{*}{$\mathbf{p}$} \\
\hline & n & $\%$ & n & $\%$ & & & \\
\hline \multicolumn{5}{|l|}{ Cinsiyet } & \multirow{3}{*}{${ }^{\mathrm{a}} 4,393$} & \multirow{3}{*}{1} & \multirow{3}{*}{${ }^{\mathrm{a}} 0,116$} \\
\hline $\mathrm{K} 1 \mathrm{Z}$ & 12 & 38,7 & 22 & 64,7 & & & \\
\hline Erkek & 19 & 61,3 & 12 & 35,3 & & & \\
\hline \multicolumn{5}{|c|}{ Anne Öğrenim Durumu } & \multirow{4}{*}{${ }^{b} 1,654$} & \multirow{4}{*}{-} & \multirow{4}{*}{${ }^{\mathrm{b}} 0,687$} \\
\hline Ortaokul & 2 & 6,5 & 4 & 11,8 & & & \\
\hline Lise & 10 & 32,3 & 11 & 32,4 & & & \\
\hline Üniversite ve üstü & 19 & 61,2 & 19 & 55,8 & & & \\
\hline \multicolumn{5}{|c|}{ Baba Öğrenim Durumu } & \multirow{4}{*}{ b3,062 } & \multirow{4}{*}{-} & \multirow{4}{*}{${ }^{\mathrm{b}} \mathbf{0 , 3 8 3}$} \\
\hline Ortaokul & - & - & 2 & 5,9 & & & \\
\hline Lise & 10 & 32,3 & 15 & 44,1 & & & \\
\hline Üniversite ve üstü & 21 & 67,7 & 17 & 50 & & & \\
\hline \multicolumn{5}{|l|}{ Ekonomik Durumu• } & \multirow{3}{*}{${ }^{\mathrm{a}} 0,682$} & \multirow{3}{*}{1} & \multirow{3}{*}{${ }^{\mathrm{a}} 0,409$} \\
\hline Orta & 15 & 48,4 & 13 & 38,2 & & & \\
\hline \multirow[t]{2}{*}{ İyi } & 16 & 51,6 & 21 & 61,8 & & & \\
\hline & Ort \pm ss & Ortanca & Ort \pm ss & Ortanca & $\mathbf{z}$ & sd & $\mathbf{p}$ \\
\hline Ailedeki birey sayısı & $3,87 \pm 0,81$ & 4 & $3,82 \pm 0,67$ & 4 & $-0,290$ & - & ${ }^{\mathrm{c}} 0,772$ \\
\hline Yaş & $11,61 \pm 0,56$ & 12 & $11,56 \pm 0,56$ & 12 & $-0,651$ & - & c0,515 \\
\hline
\end{tabular}

- Ailelerin ekonomik durumu ile ilgili değerlendirme ebeveynlerin kendi ifadeleridir.

${ }^{\text {aPearson }}$ ki-kare test, ${ }^{\mathrm{b}}$ Fisher-Freeman-Halton exact test, ${ }^{\mathrm{c}}$ Mann Whitney U test.

Tablo 2: Girişim Öncesi Deney ve Kontrol Grubunun BKİ ve Bazı Antropometrik Ölçümleri Karşılaştırılması (N=65)

\begin{tabular}{lccccc}
\hline $\begin{array}{l}\text { Antropometrik } \\
\text { Ölçümler }\end{array}$ & $\begin{array}{c}\text { Deney Grubu } \\
\text { Ort } \pm \text { SS (Min-Mak) }\end{array}$ & $\begin{array}{c}\text { Kontrol Grubu } \\
\text { Ort } \pm \text { SS (Min-Mak) }\end{array}$ & $\begin{array}{c}\text { Toplam } \\
\text { Ort } \pm \text { SS (Min-Mak) }\end{array}$ & ${ }^{\mathrm{d}} \mathbf{t} /{ }^{\mathrm{c}} \mathbf{z}$ & $\mathbf{p}$ \\
\hline Vücut ağırlığı & $58,66 \pm 10,12(44,1-84,4)$ & $57,91 \pm 10,86(38-83)$ & $58,27 \pm 10,44(38-84,4)$ & ${ }^{\mathrm{d}} \mathbf{0 , 2 8 7}$ & $\mathbf{0 , 7 7 5}$ \\
\hline Boy uzunluğu & $1,56 \pm 0,07(1,42-1,67)$ & $1,55 \pm 0,08(1,37-1,76)$ & $1,55 \pm 0,07(1,37-1,76)$ & ${ }^{\mathrm{d}} \mathbf{0 , 4 7 8}$ & $\mathbf{0 , 6 3 4}$ \\
\hline Bel çevresi & $80,71 \pm 8,56(68-107)$ & $80,97 \pm 9,69(67-105)$ & $80,85 \pm 9,10(67-107)$ & ${ }^{\mathrm{d}} \mathbf{- 0 , 1 1 5}$ & $\mathbf{0 , 9 0 9}$ \\
\hline BKİ $\left(\mathbf{k g} / \mathbf{m}^{2}\right)$ & $24,03 \pm 2,89(20,45-31,53)$ & $23,95 \pm 3,17(20-32,83)$ & $23,99 \pm 3,02(20-32,83)$ & ${ }^{\mathrm{c}} \mathbf{- 0 , 1 7 7}$ & $\mathbf{0 , 8 5 9}$ \\
\hline
\end{tabular}

'Mann Whitney U test, 'Student's t test. 
Deney ve kontrol grupları arasında BETÖ skorları bakımından istatistiksel olarak anlamlı fark saptanmadı $(\mathrm{p}>0,05)$ (Tablo 5).

Deney ve kontrol grubu katılımcilarda BETÖ skorlarında gözlenen değişimin istatistiksel olarak anlamlı olmadığı saptand $1(\mathrm{p}>0,05)$ (Tablo 4$)$.

Tablo 4'de deney ve kontrol grupları arasındabaşlangıç ölçümlerine göre 6. ay, başlangıç ölçümlerine göre 9. ay, 6. ay ölçümlerine göre 9. ay BETÖ skorlarında gözlenen değişimler bakımından istatistiksel olarak anlamlı fark saptanmadi $(\mathrm{p}>0,05)$.

Adölesanların deney grubunda ilk ölçümde BEDO ölçeği psikolojik (bağımlı) yeme davranışı puan ortalaması
24,68 $\pm 8,87$ (sağlıklı beslenme-egzersiz davranışı puan ortalaması 49,68 $\pm 8,5$ sağlıksız beslenme-egzersiz davranışı puan ortalaması $34,06 \pm 6,39$, öğü düzeni alt boyutu puan ortalaması 24,58 $\pm 3,50$ olarak bulundu (Tablo 5).

Deney ve kontrol grupları arasında 1. ölçüm (başlangıç), 2. ölçüm (6. ay) ve 3. ölçüm (9. ay) BEDÖ ölçeği alt boyutları skorları bakımından istatistiksel olarak anlamlı fark saptanmadi $(\mathrm{p}>0,05)$.

Deney ve kontrol grupları arasında başlangıç ölçümlerine göre 6. ay, başlangıç ölçümlerine göre 9. ay 6. ay ölçümlerine göre 9. ay BEDÖ ölçeği ve alt boyutları skorlarında gözlenen değişimler bakımından istatistiksel olarak anlamlı fark saptanmadi $(\mathrm{p}>0,05)$ (Tablo 5).

Tablo 3: Adölesanların Ölçümlere Göre BKİ Durumlarının Karşılaştırılması (N=65)

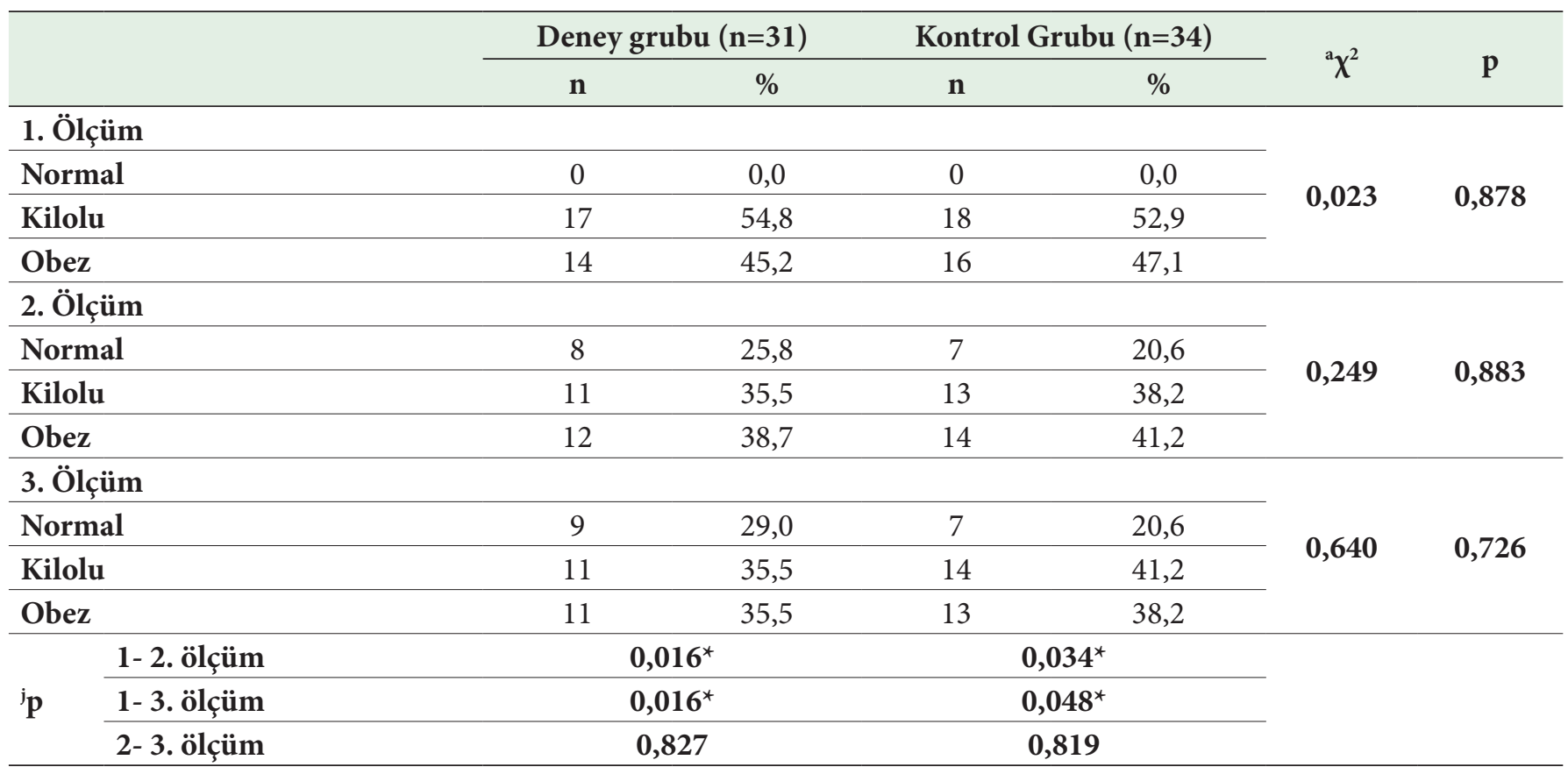

a'Pearson ki-kare test, ${ }^{j}$ MarginalHomogeneity test, ${ }^{*} \mathrm{p}<0,05$.

Tablo 4: 5210 Kilo Yönetimi Programı Öncesi ve Sonrası BETÖ Puan Ortalama ve Farkları (N=65)

\begin{tabular}{|c|c|c|c|c|c|c|}
\hline \multirow{2}{*}{ BETÖ } & \multicolumn{2}{|c|}{ Deney grubu $(\mathrm{n}=31)$} & \multicolumn{2}{|c|}{ Kontrol Grubu $(n=34)$} & \multirow{2}{*}{${ }^{d} \mathbf{t}$} & \multirow{2}{*}{$\mathbf{p}$} \\
\hline & Ort \pm SS & Min-Mak & Ort \pm SS & Min-Mak & & \\
\hline 1.Ölçüm & $47,77 \pm 6,25$ & $33-57$ & $49,56 \pm 6,62$ & $36-62$ & $-1,114$ & 0,270 \\
\hline 2.Ölçüm & $47,16 \pm 7,98$ & $29-64$ & $48,09 \pm 7,01$ & $32-60$ & $-0,499$ & 0,620 \\
\hline \multirow[t]{2}{*}{ 3.Ölçüim } & $48,52 \pm 7,48$ & $30-61$ & $47,79 \pm 7,55$ & $35-60$ & 0,387 & 0,700 \\
\hline & \multicolumn{2}{|c|}{ F:0,333; p:0,718 } & \multicolumn{2}{|c|}{$F: 0,940 ; p: 0,396$} & & \\
\hline Farklar & Ort $\pm S S$ & it; p & Ort \pm SS & ${ }^{i}$; $; \mathbf{p}$ & $\mathrm{d}_{\mathbf{t}}$ & $\mathbf{p}$ \\
\hline 2.-1.ölçüm fark & $-0,61 \pm 10,02$ & $\mathrm{t}: 0,340 ; \mathrm{p}: 0,736$ & $-1,47 \pm 9,09$ & $t: 0,943 ; p: 0,353$ & 0,362 & 0,719 \\
\hline 3.-1.ölçüm fark & $0,74 \pm 9,86$ & $t:-0,419 ; p: 0,678$ & $-1,76 \pm 7,63$ & t:1,349; p:0,187 & 1,152 & 0,254 \\
\hline 3.-2.ölçüm fark & $1,35 \pm 7,71$ & t:-0,979; p:0,335 & $-0,29 \pm 7,28$ & $t: 0,235 ; p: 0,815$ & 0,887 & 0,379 \\
\hline
\end{tabular}

BETÖ: Beslenme Egzersiz Tutum Ölçeği, dStudent’s t test, ${ }^{h}$ Tekrarlı ölçümler ANOVA, ${ }^{i}$ Pairedsamples $t$ test. 
Tablo 5: 5210 Kilo Yönetimi Programı Öncesi ve Sonrası BEDÖ Puan Ortalama ve Farkları (N=65)

\begin{tabular}{|c|c|c|c|c|c|c|c|}
\hline \multirow{2}{*}{ BEDÖ } & & \multicolumn{2}{|c|}{ Deney grubu $(\mathrm{n}=31)$} & \multicolumn{2}{|c|}{ Kontrol Grubu $(\mathrm{n}=34)$} & \multirow{2}{*}{$\mathrm{d}_{\mathbf{t}}$} & \multirow{2}{*}{$\mathbf{p}$} \\
\hline & & Ort \pm SS & Min-Mak & Ort \pm SS & Min-Mak & & \\
\hline \multirow{9}{*}{$\begin{array}{l}\text { Psikolojik } \\
\text { (bağımlı) } \\
\text { Yeme } \\
\text { Davranışı }\end{array}$} & 1. Ölçüm & $24,68 \pm 8,87$ & $13-43$ & $22,59 \pm 7,14$ & $12-36$ & 1,050 & 0,298 \\
\hline & 2. Ölçüm & $24,29 \pm 9,35$ & $11-51$ & $23,76 \pm 9,43$ & $11-49$ & 0,225 & 0,822 \\
\hline & 3. Ölçüm & $25,29 \pm 9,59$ & $12-49$ & $23,44 \pm 7,56$ & $11-42$ & 0,867 & 0,389 \\
\hline & ${ }^{\mathrm{h}} \mathrm{F} ; \mathbf{p}$ & \multicolumn{2}{|c|}{$F: 0,123 ; p: 0,884$} & \multicolumn{2}{|c|}{ F:0,238; p:0,789 } & & \\
\hline & Farklar & Ort \pm SS & ${ }^{\mathrm{i}} \mathbf{t} ; \mathbf{p}$ & Ort $\pm S S$ & it; $\mathbf{p}$ & ${ }^{d} \mathbf{t}$ & $\mathbf{p}$ \\
\hline & 2.-1.ölçüm fark & $-0,39 \pm 10,81$ & $t: 0,199 ; p: 0,843$ & $1,18 \pm 10,81$ & $t:-0,635 ; p: 0,530$ & $-0,583$ & 0,562 \\
\hline & 3.-1.ölçüm fark & $0,61 \pm 12,82$ & $t:-0,266 ; p: 0,792$ & $0,85 \pm 8,85$ & $\mathrm{t}:-0,562 ; \mathrm{p}: 0,578$ & $-0,089$ & 0,930 \\
\hline & 3.-2.ölçüm fark & $1,00 \pm 10,10$ & t:-0,551; p:0,586 & $-0,32 \pm 11,06$ & $t: 0,171 ; p: 0,866$ & 0,502 & 0,617 \\
\hline & & Ort \pm SS & Min-Mak & Ort \pm SS & Min-Mak & $\mathrm{d}_{\mathbf{t}}$ & $\mathbf{p}$ \\
\hline \multirow{9}{*}{$\begin{array}{l}\text { Sağlıklı } \\
\text { Beslenme- } \\
\text { Egzersiz } \\
\text { Davranışı }\end{array}$} & 1.Ölçüm & $49,68 \pm 8,55$ & $31-64$ & $52,47 \pm 7,57$ & 32,69 & $-1,397$ & 0,167 \\
\hline & 2.Ölçüm & $51,39 \pm 9,39$ & $30-66$ & $52,12 \pm 9,55$ & $31-67$ & $-0,311$ & 0,757 \\
\hline & 3.Ölçüm & $51,19 \pm 9,85$ & $26-70$ & $49,94 \pm 10,22$ & $27-65$ & 0,502 & 0,617 \\
\hline & ${ }^{\mathrm{h}} \mathrm{F} ; \mathbf{p}$ & \multicolumn{2}{|c|}{$F: 0,590 ; p: 0,558$} & \multicolumn{2}{|c|}{$F: 1,127 ; p: 0,330$} & & \\
\hline & Farklar & Ort $\pm S S$ & it; $\mathbf{p}$ & Ort \pm SS & it; $\mathbf{p}$ & $\mathrm{d}_{\mathbf{t}}$ & $\mathbf{p}$ \\
\hline & 2.-1.ölçüm fark & $1,71 \pm 10,31$ & $t:-0,924 ; p: 0,363$ & $-0,35 \pm 10,51$ & $t: 0,196 ; p: 0,846$ & 0,798 & 0,428 \\
\hline & 3.-1.ölçüm fark & $1,52 \pm 10,28$ & t:-0,821; p:0,418 & $-2,53 \pm 10,23$ & $\mathrm{t}: 1,442 ; \mathrm{p}: 0,159$ & 1,589 & 0,117 \\
\hline & 3.-2.ölçüim fark & $-0,19 \pm 8,04$ & $t: 0,134 ; p: 0,894$ & $-2,18 \pm 11,17$ & $t: 1,136 ; p: 0,264$ & 0,814 & 0,419 \\
\hline & & Ort \pm SS & Min-Mak & Ort \pm SS & Min-Mak & $\mathrm{d}_{\mathbf{t}}$ & $\mathbf{p}$ \\
\hline \multirow{9}{*}{$\begin{array}{l}\text { Sağlıksız } \\
\text { Beslenme- } \\
\text { Egzersiz } \\
\text { Davranışı }\end{array}$} & 1. Ölçüim & $34,06 \pm 6,39$ & $18-47$ & $35,38 \pm 7,46$ & $23-56$ & $-0,761$ & 0,449 \\
\hline & 2. Ölçüm & $33,68 \pm 5,99$ & $25-45$ & $36,06 \pm 5,90$ & $27-49$ & $-1,614$ & 0,112 \\
\hline & 3. Ölçüm & $32,77 \pm 7,41$ & $19-50$ & $35,38 \pm 6,17$ & $26-51$ & $-1,547$ & 0,127 \\
\hline & ${ }^{\mathrm{h}} \mathrm{F} ; \mathrm{p}$ & \multicolumn{2}{|c|}{ F:0,334; p:0,717 } & \multicolumn{2}{|c|}{ F:0,147; p:0,863 } & & \\
\hline & Farklar & Ort \pm SS & ${ }^{\mathrm{i}} \mathbf{t} ; \mathbf{p}$ & Ort \pm SS & it; $\mathbf{p}$ & $\mathrm{d}_{\mathbf{t}}$ & $\mathbf{p}$ \\
\hline & 2.-1.ölçüm fark & $-0,39 \pm 8,99$ & $\mathrm{t}: 0,240 ; \mathrm{p}: 0,812$ & $0,68 \pm 8,15$ & $t:-0,484 ; p: 0,632$ & $-0,500$ & 0,619 \\
\hline & 3.-1.ölçüm fark & $-1,29 \pm 10,24$ & $t: 0,701 ; p: 0,489$ & $0,00 \pm 9,04$ & $t: 0,000 ; p: 1,000$ & $-0,539$ & 0,592 \\
\hline & 3.-2.ölçüm fark & $-0,90 \pm 7,63$ & $t: 0,659 ; p: 0,515$ & $-0,68 \pm 7,95$ & $t: 0,496 ; p: 0,623$ & $-0,117$ & 0,907 \\
\hline & & Ort \pm SS & Min-Mak & Ort \pm SS & Min-Mak & $\mathrm{d}_{\mathbf{t}}$ & $\mathbf{p}$ \\
\hline \multirow{8}{*}{$\begin{array}{l}\text { Öğüun } \\
\text { Düzeni }\end{array}$} & 1.Ölçüm & $24,58 \pm 3,50$ & $15-30$ & $24,15 \pm 4,06$ & $16-30$ & 0,459 & 0,648 \\
\hline & 2.Ölçüm & $24,10 \pm 3,78$ & $17-30$ & $23,29 \pm 5,05$ & $12-30$ & 0,720 & 0,474 \\
\hline & 3.Ölçüm & $24,77 \pm 4,36$ & $14-30$ & $22,68 \pm 5,30$ & $12-30$ & 1,733 & 0,088 \\
\hline & ${ }^{\mathrm{h}} \mathrm{F} ; \mathrm{p}$ & \multicolumn{2}{|c|}{$F: 0,256 ; p: 0,728$} & \multicolumn{2}{|c|}{$F: 1,167 ; p: 0,312$} & & \\
\hline & Farklar & Ort $\pm S S$ & it $; \mathbf{p}$ & Ort \pm SS & it $; \mathbf{p}$ & $\mathrm{d}_{\mathbf{t}}$ & $\mathbf{p}$ \\
\hline & 2.-1.ölçüm fark & $-0,48 \pm 5,69$ & t:0,473; p:0,639 & $-0,85 \pm 5,19$ & t:0,958; p:0,345 & 0,273 & 0,785 \\
\hline & 3.-1.ölçüm fark & $0,19 \pm 6,34$ & $t:-0,170 ; p: 0,866$ & $-1,47 \pm 4,83$ & $\mathrm{t}: 1,775 ; \mathrm{p}: 0,085$ & 1,197 & 0,236 \\
\hline & 3.-2.ölçüm fark & $0,68 \pm 3,98$ & $t:-0,948 ; p: 0,351$ & $-0,62 \pm 6,71$ & t:0,537; p:0,595 & 0,935 & 0,353 \\
\hline
\end{tabular}

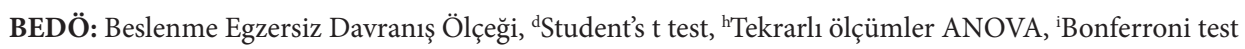




\section{TARTISSMA}

Meydanlığlu (2013)'nun ilköğretim 4. sinıflarda (64 deney, 50 kontrol) 6 haftalık beslenme ve fiziksel aktivite eğitimi uyguladığı SİBFAB isimli çalışmasında deney grubunda antropometrik ölçümlerde anlamlı bir değişim saptanmamıştır. Törüner (2009)'in ilköğretim 4. sinıflarda (41 deney, 40 kontrol) 10 haftalık kilo yönetimi programı sonrası deney grubundaki çocukların kontrol grubundakilere göre üçüncü ölçümde BKİ değerlerinin anlamlı derecede azaldığı bulunmuştur $(\mathrm{p}<0,05)$. Yurt (2008)'un çalışmasında 12-14 yaş grubu adölesanlara üç aylık süre ile motivasyon görüşmelerinin kilo verme üzerinde etkili olduğu tespit edilmiştir. Kriemler ve ark. nın (2010) 1 yıl boyunca uyguladıkları okul temelli fiziksel aktivite programı sonucunda çocuklarda yağlanma azalmıştır (29-31).

Ardıç (2014)'nın 12-15 yaş (45 deney, 42 kontrol) grubuna uyguladığı 15 haftalık "Adölesan Sağlığını GeliştirmeFiziksel Aktivite, Beslenme, Stres Yönetimi Programı” nın BKİne etkisi anlamlı bulunmamıștır (32).

Araştırma kapsamında deney ve kontrol grubundaki adölesanların BKİleri bașlangıç, 6.ayda ve 9. ayda toplam $3 \mathrm{kez}$ ölçüldü. Deney ve kontrol grupları arasında 1. ölçüm (başlangıç) 2. ölçüm (6. ay), 3. ölçüm (9. ay). BKİ durum dağılımları ve BKİ değerleri bakımından Meydanlığlu ve Ardıç'ın çalışmasına benzer olarak istatistiksel olarak anlamlı farklılık saptanmamasına karşın $(\mathrm{p}>0,05)$, deney grubunda 1. ölçüm (başlangıç) BKİ durum dağılımlarına göre 2. ölçüm (6. ay), birinci ölçüm (başlangıç) BKİ durum dağılımlarına göre 3. ölçüm (9. ay) BKİ durumları dağılımlarında gözlenen değişimin istatistiksel olarak anlamlı olduğu saptandı (p:0,016).

Birinci ölçüme göre ikinci ve üçüncü ölçümde BKİ değeri normal olan adölesanların oranının arttığı gözlendi. Deney grubunda 2. ölçümde 8 öğrenci, 3. ölçümde 1 öğrenci olmak üzere çalışma sonunda 9 öğrenci normal BKİ değerlerinde ölçüldü.

Tablo 3'de deney grubu adölesanlarda başlangıç, 6. ay ve 9. ay BKİ ölçümlerinde gözlenen değişimin istatistiksel olarak anlamlı olmadığı saptandı $(\mathrm{p}>0,05)$. Kontrol grubu adölesanlarda başlangıç, 6 . ay ve 9. ay BKİ ölçümlerinde gözlenen değişimin istatistiksel olarak anlamlı olduğu saptandı (p:0,001; p<0,01). Başlangıç ölçümlerine göre 6. ay ölçümlerinde gözlenen ortalama 0,52 $\pm 1,30$ birimlik artışın, başlangıç ölçümlerine göre 9. ay ölçümlerinde gözlenen ortalama $1,01 \pm 1,52$ birimlik artışın, altıncı ay ölçümlerine göre 9. ay ölçümlerinde gözlenen ortalama $0,49 \pm 0,68$ birimlik artışın istatistiksel olarak anlamlı olduğu saptandı $(\mathrm{p}<0,01)$. Ancak Tablo 3'de deney grubundaki adölesanların başlangıç ölçümlerine göre 9. ay ölçümlerinde gözlenen değişimin kontrol grubu adölesanlarda aynı süreçte gözlenen değişimden istatistiksel olarak anlamlı olmamakla birlikte dikkat çekici düzeyde düşük olduğu saptandı ( $p: 0,082 ; p>0,05)$. Kontrol grubu hizla kilo almaya devam ederken deney grubunun normal gelișimlerini sürdürdüğü ve kontrol grubuna göre daha az kilo aldıkları söylenebilir. Adölesan dönemdeki obezite ile etkili mücadele edilmezse yetişkinlikte önemli sağlık sorunları ile birlikte ilerleyen, bireyin yaşam kalitesini etkileyen kronik bir durum olarak ilerleyecektir.

5210 kilo yönetimi programı öncesi ve sonrası adölesanların beslenme ve egzersiz tutumları BETÖ ölçeği ile başlangıç, 6 . ayda ve 9. ayda değerlendirildi.

Yurt'un çalışmasında (2008) 12-14 yaş grubu adölesanlara üç aylık süre ile uygulanan motivasyon görüşmeleri öğrencilerin beslenme ve egzersiz tutumlarını olumlu yönde geliştirmelerinde etkili olmuştur. Girişim öncesi BETÖ ortalama puanı $45,96 \pm 1,14$ girişim sonrası ortalama puan $51,75 \pm 1,17$ olarak bulunmuş, aradaki fark istatistiksel olarak anlamlı bulunmuştur (26).

Bu çalışmada deney grubu adölesanlarda BETÖ ölçeği puan ortalamaları başlangıçta Yurt'un çalışmasına benzer olarak $47,77 \pm 6,25,6$ ayda $47,16 \pm 7,98$ ve 9 . Ayda $48,52 \pm 7,48$ olarak bulundu (Tablo 4 ).

Deney ve kontrol grupları arasında 1. ölçüm (başlangıç), 2. ölçüm (6. ay) ve 3. ölçüm (9. ay) BETÖ skorları bakımından istatistiksel olarak anlamlı fark saptanmadı $(\mathrm{p}>0,05)($ Tablo $4)$.

Deney grubu öğrencilerde başlangıç, 6. ay ve 9. ay BETÖ skorlarında gözlenen değișimin istatistiksel olarak anlamlı olmadığ1 saptandı $(\mathrm{p}>0,05)$. Kontrol grubu öğrencilerde başlangıç, 6. ay ve 9. ay BETÖ skorlarında gözlenen değişimin istatistiksel olarak anlamlı olmadığı saptandı $(\mathrm{p}>0,05)$. Deney ve kontrol grupları arasında başlangıç ölçümlerine göre 6. ay, başlangıç ölçümlerine göre 9. ay, 6. ay ölçümlerine göre 9. ay BETÖ skorlarında gözlenen değişimler bakımından istatistiksel olarak anlamlı fark saptanmadı ( $>00,05)$, (Tablo 4). Bu çalışmada ölçümler arası sürenin uzun olmasının ve adölesanların son ölçümde Temel Eğitimden Ortaöğretime Geçiş Sınavı (TEOG) sınavına girmiş olmalarının ve velilerle işbirliği ve katılımın yetersiz olmasının beslenme-egzersiz tutumlarını olumsuz etkileyebileceğini düşündürdü.

5210 kilo yönetimi programı öncesi ve sonrası adölesanların beslenme ve egzersiz davranışları BEDÖ ölçeği ile başlangıç, 6. ayda ve 9. ayda değerlendirildi.

Yurt (2008)'un çalışmasında 12-14 yaş grubu adölesanlara üç aylık süre ile uygulanan motivasyon görüşmelerinin BEDÖ ölçeğinin sağlıklı beslenme egzersiz davranışı alt boyutu üzerinde etkili olduğu tespit edilmiştir (26). 
Geçgil ve Yıldız Malatya'da 122 lise öğrencisine içinde beslenme ve stresle başetmenin de bulunduğu sağliklı yaşam biçimi konusunda 8 haftalık eğitim vermişlerdir. Altı ay sonra Sağlıklı Yaşam Biçimi Davranışları Ölçeği (SYBDÖ) kullanarak yaptıkları değerlendirme sonucunda adölesanların beslenmeye yönelik sağlık davranışlarında (sabahları kahvaltı yapma, koruyucu ve katkı maddesi içeren gidalar almama, her gün düzenli üç ögün beslenme, ambalajlı gıdaların etiketini okuma, posalı ve lifli yiyeceklere yer verme, her gün dört besin grubunu içeren öğün planlama) artış olduğunu bulmuşlardır (33).

Neumark-Sztainer ve Story (2003)'nin “New Moves” isimli 9.-12.sinif14-17 yaşında (89 deney, 112 kontrol) sadece kızlardan oluşan adölesan gruba 16 hafta süresince fizik aktivite, tv izleme, meyve -sebze tüketimi, ağırlık kontrolü bileşenlerini içeren program uygulamışlar ve sonuçta fiziksel aktivite davranışları dışında deney ve kontrol grubunda olumlu bir değişiklik bulunmamıștır (34).

İversen ve ark.nın (2001) "Fun 5" isimli 9-12 yaş grubunda $(\mathrm{n}=119)$ yaptığı Randomize kontrollü çalışmalarında bir yıl süre ile beslenme, fiziksel aktivite ve sebze- meyve tüketiminin arttırılmasına yönelik girişimler uygulanmış, sonuçta program sebze- meyve tüketimi ve fiziksel aktivitenin geliştirilmesinde etkili olmuştur (35).

Kriemler ve ark.nın (2010) "KISS" isimli sosyoekolojik modeli temel alan, ilköğretim öğrencilerine yönelik (deney: 297, kontrol: 205) okul temelli fiziksel aktivite programı sonucunda okul tabanlı birden fazla aktivite uygulanmasının çocuklarda yağlanmayı azalttığı bulunmuştur (36).

Törüner'in (2009) ilkokul 4. sınıflarda sosyal bilişsel teori temelli 10 haftalık eğitim programının kilo yönetiminde etkili olduğu bulunmuş, benzer şekilde Meydanlığlu (2013)'nun ilköğretim 4. sinıflarda (64 deney, 50 kontrol) 6 haftalık beslenme ve fiziksel aktivite eğitimi uyguladığg 1 SİBFAB isimli çalışmada SİBFAB'ın beslenme ve egzersiz davranışını geliştirmede etkili olduğu bulunmuştur (31).

Ardıç (2014)'nın 12-15 yaş (45 deney, 42 kontrol) grubuna uyguladığı 15 haftalık "Adölesan Sağlığını GeliştirmeFiziksel Aktivite, Beslenme, Stres Yönetimi Programı" sonucunda girişim sonrası programa katılan adölesanlarda haftalık adım sayısı, beslenme fizilsel aktivite ve stres yönetimi davranışları, meyve ve sebze tüketimi, günlük içilen su miktarı, beslenme ve fiziksel aktivite bilgi düzeyinde anlamlı artış; kiloda, anksiyete ve depresyon semptomlarında anlamlı azalma görülmüştür (32).

$\mathrm{Bu}$ çalışmada adölesanların deney grubunda ilk ölçümde BEDO ölçeği psikolojik (bağımlı) yeme alt boyut puan ortalaması $24,68 \pm 8,87$, sağlıklı beslenme-egzersiz alt boyut puan ortalaması $49,68 \pm 8,5)$, sağlıksı beslenme-egzersiz alt boyut puan ortalaması $34,06 \pm 6,39$ ile $24,58 \pm 3,50$ olarak bulundu (Tablo 5). Yurt ve ark.nın (2012) Düzce ilinde
6,7,8. sınıflarda BEDÖ ölçeğini kullanarak yapmış oldukları çalışmada $(\mathrm{n}=412)$ psikolojik (bağımlı) yeme davranışı puan ortalaması 40,34, sağlıklı beslenme-egzersiz davranışı puan ortalaması 50,29, sağlıksız beslenme-egzersiz davranışı puan ortalaması 49,08, öğün düzeni alt boyutu puan ortalaması 23,58 olarak bulunmuştur.

Yurt'un (2008) İstanbul'da yapmış olduğu çalışmada ( $\mathrm{n}=32$ ) psikolojik (bağımlı) yeme davranışı puan ortalaması 36,15 , sağlıklı beslenme-egzersiz davranışı puan ortalaması 46,34, sağlıksız beslenme-egzersiz davranışı puan ortalaması 44,40 , öğün düzeni alt boyutu puan ortalaması 20,75 olarak bulunmuştur (26).

Bu çalışmada psikolojik (bağımlı) yeme davranış puanının her iki çalışmaya göre daha az düzeyde olduğu, sağlıklı beslenme ve ögün düzeni puan ortalamalarının benzer olduğu, sağlıksız beslenme-egzersiz davranışının diğer çalışmalara göre daha az sergilendiği söylenebilir. $\mathrm{Bu}$ farklılığın bu çalışmadaki okulların özel okul olması nedeni ile psikolojik rehberlik, danışmanlık hizmetlerinin her öğrenciye ulaşması, okul çevresindeki sağlıklı beslenme spor olanaklarının farklı olmasından kaynaklandığı düşünüldü.

Deney ve kontrol grupları arasında 1.ölçüm (başlangıç), 2. ölçüm (6. ay) ve 3. ölçüm (9. ay) BEDÖ ölçeği psikolojik (bağımlı) yeme davranışı, sağlıklı beslenme-egzersiz davranışı, sağlıksız beslenme-egzersiz davranışı, öğün düzeni alt boyutları skorları bakımından istatistiksel olarak anlamlı fark saptanmadı ( $>0,05)$ (Tablo 5).

Deney grubu adölesanlarda başlangıç, 6. ay ve 9. ay BEDÖ ölçeği ve alt ölçekleri skorlarında gözlenen değişimin istatistiksel olarak anlamlı olmadığı saptandı $(p>0,05)$ (Tablo 5). Kontrol grubu adölesanlarda başlangıç, 6. ay ve 9 ay BEDÖ ölçeği psikolojik (bağımlı) yeme davranışı, sağlıklı beslenme-egzersiz davranışı, sağlıksız beslenmeegzersiz davranışı, öğün düzeni skorlarında gözlenen değişimin istatistiksel olarak anlamlı olmadığı saptandı $(\mathrm{p}>0,05)$ (Tablo 5).

Deney ve kontrol grupları arasında başlangıç ölçümlerine göre 6.ay, başlangıç ölçümlerine göre 9. ay, 6. ay ölçümlerine göre 9. ay BEDÖ ölçeği alt boyutları skorlarında gözlenen değişimler bakımından istatistiksel olarak anlamlı fark saptanmadı ( $>0,05)$ (Tablo 5). Bu sonuçlar aile tutumları, öğretmenler, okul kantinleri, besin hazırlama davranışları gibi faktörlerin de beslenme tutumuna yönelik programlarda göz önünde bulundurulması gerektiğini düşündürdü.

Törüner ve Savaşer (2010)' in en az 4 ay en fazla 3 yll süren 16 adet okula dayalı girişim içeren çalışmayı inceledikleri araştırmalarında çocuklarda obezliği önlemeye yönelik okula dayalı girişimlerde, beslenme, fiziksel aktivite ve televizyon seyretme gibi alışkanlıkların değiştirilmesi üzerinde durulması, programların başarısını etkilemektedir. Ayrıca çoklu girişimlerin tek yönlü girişimlere göre daha başarılı 
olduğunu belirmişlerdir (37). Bu çalışmada 5210 Kilo Yönetimi Eğitim Programının adölesanların beslenme-egzersiz tutum ve davranışlarını etkilememesinde çoklu girişimlerin (okul öğretmenleri, anne ve babalara eğitim seansları, daha fazla uygulamalı fizik aktivite dersleri...) yeterince uygulanamamasının rolü olabilir. İncelenen araştırma sonuçları adölesanlarda sağlıklı yaşam konusunda davranış değişikliğinin uzun süreli eğitim programlarıyla (en az 4 ay) gerçekleştiğini göstermektedir (26,35-38).

Okullarda çocuk ve adölesanlarda sağlıklı kilo hedefine ulaşmak ve sağlıklı beslenme ve fiziksel aktivite davranışlarını geliștirmek amacı ile Allensworth ve Kolbe tarafından geliştirilen kapsamlı entegre modelde sağlık eğitimi programlarının yanında fiziksel aktivite eğitim sınıfları, okul rehberlik ve psikolojik danışmanlık programları, okuldaki personel ve öğrenciler için sağlığı geliştirme programları, aile ve toplum bağlantıları, okul beslenme çevresi, okul sağlı̆̆ı birimleri, okul yiyecek servisi gibi bileşenlerin de ele alınması gerektiği vurgulanmaktadır (38).

Eğitim programı ve ön test uygulandıktan sonra öğrencilerin yaz tatiline girmesi nedeni ile birinci izlem ve son test 6 ay sonra yapılabildi. Son izlem döneminde (9. ay) öğrencilerin TEOG stresini yaşamaları beslenme ve egzersiz davranışlarını etkilemiş olabilir. Velilerle işbirliği sınırlı düzeyde gerçekleştirilebildi. Ailelere bir kez tanışma toplantısı dışında katılım sınırlı olduğundan yüz yüze eğitim verilemedi, eve broşürler gönderildi.

Sonuç olarak 5210 beslenme programının adölesanların kilo durumları üzerinde etkili olduğu deney grubunda başlangıçta adölesanların \%54'ü kilolu (17 kişi), \%45’i obez (14 kişi) iken son ölçümde \%29'u normal (9 kişi),\% 35,4'i kilolu (11kişi), \%35,4'i obez (11 kişi) olarak tespit edildi. Kontrol grubu hizla kilo almaya devam ederken deney grubunun normal gelişimlerini sürdürdüğü ve kontrol grubuna göre daha az kilo aldıkları söylenebilir. 5210 kilo yönetimi programının adölesanların BETÖ puan ortalamaları ve BEDÖ ve alt ölçekleri puan ortalamalarını etkilemediği bulundu. Bu sonuçlar doğrultusunda 5210 kilo yönetimi programının çoklu girişimler eklenip, program süresi arttırıldığında daha etkili olacağı düşünüldü.

Bu sonuçlar doğrultusunda;

- 5210 kilo yönetimi programına çoklu girişimlerin entegre edilerek uygulanması (aile, öğretmenler, okul çevresi, daha fazla fiziksel aktivite girişimleri...),

- Program başarısını arttırmak için motivasyon görüşmeleri gibi bireysel girişimlerin de programa entegre edilmesi,

- Sınav dönemlerinde öğrencilere beslenme programlarınin uygulanmamasi,

- Program süresinin uzatılması,
- Programa ebeveynlerin aktif katılımının sağlanması ve programin ebeveynler üzerinde etkisinin değerlendirilmesi önerildi.

\section{Teşşekküir}

Çalışmaya katılan okulların yönetici ve öğretmenlerine, öğrenci ve velilere, Dr. Öğr. Ü. Ayşe YILDIZ'a teşekkür ederim.

\section{KAYNAKLAR}

1. Kıllı̧ İ, Derman O, Kanbur NÖ, Aksoy C. Obez adölesanlardaki ortopedik sorunlar. Hacettepe Üniversitesi 1.Ulusal Adölesan Sağllğı Kongresi, Ankara, Kongre Kitabı. Ankara, 2006:s 256281.

2. Stang J and Story M (eds), Guidelines for Adolescent Nutrition Services (2005), retrieved on 30th June, 2014 from http://www. epi.umn.edu/let/pubs/adol_book.shtm. http://www.epi.umn. edu/let/pubs/img/adol_preface_materials.pdf., erişim tarihi: 10.07.2014

3. WHO. (2012). Global Strategy on Diet, Physical Activity and Health. http://www.who.int/dietphysicalactivity/childhood/ en/index.html., erişim tarihi: 16 Mayıs 2013.

4. WHO. (2013a). http://www.who.int/topics/adolescent_health/ en/ , Erişim tarihi: 7.02.2013.

5. WHO Avrupa Bölge Ofisi .(2013).Bulaşıcı Olamayan Hastalıkların Önlenmesine ve Kontrolüne İlişkin Küresel eylem Plan (2013-2020) http://www.thsk.gov.tr/dosya/birimler/ kronik_hastaliklar/dokumanlar/2015-kuresel_eylem_plani/ kuresel_eylem_plani.pdf, erişim tarihi: 20.02.2015 .

6. WHO. Obesity and Overweight Fact Sheet No: 311,2014. http://www.who.int/mediacentre/factsheets/fs311/en/ ., erişim tarihi: 28.05 .2014

7. WHO. Global status report on noncommunicable diseases 2010. s:24 Geneva, http://www.who.int/nmh/publications/ ncd_report_full_en.pdf., erişim tarihi, 26.05.2014.

8. World HealthOrganization .(1993). TheHealth Of Young People; A Challange andPromise,Genneva.http://apps. who.int/iris/handle/10665/37353? mode=simple\&submit_ simple $=$ Show + simple+item + record erişim tarihi:28.05.2014.

9. WHO. (2007). Thechallenge of obesity in the WHO European Region and the strategies for response: summary. Copenhagen WHO regional Office for Europe.

10. Baltacı G, Ersoy G, Kararağaolu N. Ergenlerde Sağlıklı Beslenme ve Hareketli Yaşam. Sağlık Bakanlığı Yayını: Ankara, 2012:730.

11. WHO. (2014a). HealthForThe World Adolescents A Second Change İn The Second Decatehttp://apps.who.int/iris/ bitstream/10665/112750/1/WHO_FWC_MCA_14.05_eng. pdf?ua=1., erişim tarihi: 28.05.2014.

12. Sağlık Bakanlığı Türkiye Halk Sağlığı Kurumu. Birinci Basamak Hekimler İçin Obezite İle Mücadele El Kitabı; Çocukluk ve Adölesan Döneminde Obezite 2013; s:53-87.

13. HBSC. (2009). http://www.hbsc.org/publications/ international/ erişim tarihi: 21.05.2014 
14. NCHS Data Brief No:82. (2012). http://www.cdc.gov/nchs/ data/databriefs/ db82.pdf., erişim tarihi:21.05.2014

15. Türkiye'de Okul Çağı Çocuklarında (6-10 Yaş Grubu) Büyümenin İzlenmesi Projesi Araştırma Raporu (TOÇBİ). (). Sağlık Bakanlığı, Hacettepe Üniversitesi Sağlık Bilimleri Fakültesi Beslenme ve Diyetetik Bölümü, T.C. Milli Eğitim Bakanlığı. Kuban Matbaacılık, Sağlık Bakanlığı Yayın No: 834, ISBN: 978-975-590-370-5. Ankara. 2011.

16. Türkiye Beslenme ve Sağlık Araştırması (TBSA). Beslenme durumu ve alışkanlıklarının değerlendirilmesi sonuç raporu (2014) Sağlık Bakanlığı, Hacettepe Üniversitesi, Sağlık Bilimleri Fakültesi, Beslenme ve Diyetetik Bölümü. T.C. Sağlık Bakanlığı Yayın No:931, Sağlık Araştırmaları Genel Müdürlüğü Yayın No: SB-SAG-2014/0. Ankara, 2014

17. Davis Matthew M, Gance-Cleveland B, Hassink S, Johnson R, Paradis G, Resnicow K. Recommendationsforprevention of chidhoodobesity. Pediatrics2007:120: s229. http://pediatrics. aappublications.org/content/123/Supplement_5/S258.full.pdf. erişim tarihi: 27.05.2014 .

18. Let'sMove! Website, http://www.letsmove.gov/about erişim tarihi: 26.05.2014.

19. Hartman, Pat. (2011). 5-2-1-0 and the Let's Go Initiative, Childhood Obesity News. Retrieved from http://childhood obesity news.com/2011/05/09/5-2-1-0-and-the-lets-goinitiative., erişim tarihi: 26.05.2014 .

20. Maine Youth Overweight Collobrative (MYOC) http://www. hsph.harvard.edu/prc/projects/clinical-interventions-toprevent-childhood overweight/., erişim tarihi: 21.05.2014.

21. Özcan, Ş, Akbayrak N. (Ed.), İlhan, SE.(Ed.), Ançel, G. (Ed.), Albayrak, A. Obezite, Hemşirelik Bakım Planları, Birlik Matbaası, Ankara. 2007; S: 473-477.

22. NASN.(2013).ShanksB,Lechtenbergj,DelgerS.Overweightand Obesity in Youth in Schools - The Role of the School Nurse.http:// www.nasn.org/PolicyAdvocacy/PositionPapersandReports/ NASNPositionStatementsArticleView/tabid/462/ArticleId/39/ Overweight-Children-and-Adolescents-Adopted-2002., erişim tarihi: 20.08.2014.

23. Carter R.C. The impact of public schools on childhood obesity. Journal Of American Medical Association 2002;288:2180.

24. O’Toole TP, Anderson S, Miller C, Guthrie J. Nutrition services and foods and beverages avaiable at school: results from the school health policies and programs study. Journal of School Health 2007;77(8);500-521.

25. CleaMcNeely MA, Blanchard J. The Teen Years Explaned, A Guide To Healthy Adolescent Development, 2014; p:15-16, http://www.jhsph.edu/research/centers-and-institutes/centerfor-adolescent-health/_includes/Interactive\%20Guide.pdf., erişim tarihi: 05.06.2014

26. Yurt S. Fazla Kilolu Adölesanlara Uygulanan Motivasyon Görüşmelerinin Beslenme Tutumu, Davranışları ve Kilo Üzerine Etkisi. Marmara Üniversitesi SBE. Halk Sağlı̆̆ Hemşireliği ABD Doktora Tezi. (Danışman: Ayşe YILDIZ), 2008.
27. Neyzi O, Günöz Ö, Furman A ve ark. Türk çocuklarında vücut ağırlığı, boy uzunluğu, baş çevresi ve Beden Kitle İndeksi referans değerleri. Çocuk Sağlı̆̆ı ve Hastalıkları Dergisi 2008;51:1-14

28. Türkiye'de Okul Çağı Çocuklarında (6-10 Yaş Grubu) Büyümenin İzlenmesi Projesi Araştırma Raporu (TOÇBİ). Sağlık Bakanlığı, Hacettepe Üniversitesi Sağlık Bilimleri Fakültesi Beslenme ve Diyetetik Bölümü, T.C. Milli Eğitim Bakanlığı. Kuban Matbaacılık, Sağlık Bakanlığı Yayın No: 834, ISBN: 978-975-590-370-5. Ankara, 2011.

29. Meydanlığlu A. Hemşire Liderli Sağlik İçin Beslenme ve Fiziksel Aktivite Programi’nın Çocuklarin Beslenme ve Fiziksel Aktivite Düzeylerine Etkisi. Doktora Tezi, Marmara Ü. SBE, Halk Sağlığı Hemşireliği ABD (Danışman: Ayşe YILDIZ), 2013.

30. Törüner Kılıçarslan E.Obez okul çağı çocuklarında kilo yönetimi programının uygulanması. İstanbul Üniversitesi SBE, Çocuk Sağlığı ve Hast. ABD, Doktora Tezi. (Danışman: Prof. Dr. Sevim SAVAŞER), 2009.

31. Ardıç A.(2014). Adölesan Sağlığını Geliştirme Programının Erken Adölesan Dönemi Çocukların Beslenme, Fiziksel aktivite ve Ruh sağlı̆̆1 Üzerine Etkisi. İstanbul Üniversitesi SBEHalk Sağlığı Hemşireliği Anabilim Dalı. (Danışman:Prof. Dr. Semra Erdoğan) Doktora Tezi. 2014 .

32. Geçgil E, Yıldız S. Adölesanlara yönelik beslenme ve stresle başetme eğitiminin sağlığı geliştirmeye etkisi. C.Ü. Hemşirelik Yüksekokulu Dergisi 2006;10(2): 19-28.

33. Neumark-Sztainer D, Story M, Hannan, P.J., Rex, J. (). New moves; a school-based obesity prevention program for adolescent girls. Prev Med 2003;37(1):41-5.

34. Iversen MS, Nigg C, Titchenal AC. The impact of an elementary after-school nutrition and phsical activity program on children's fruit and vegetable intake, physical activity and body massindex: Fun 5. Hawai'1 Medical Journal2011,;0(1):37-41.

35. Kriemler S, Zahner L, Schindler C, Meyer U, Hartmann T, Hebestreit H, Brunner-La Rocca HP, Van Mechelen W, Puder JJ. Effect of school based physical activity programme (KISS) on fitness and adiposity in primary school children: cluster randomised controlled trial. BMJ 2010;340:c785

36. Törüner, Kılıçarslan, E.,Savaşer S. Okulçağı çocuklarında obezliğın önlenmesi ve erken tedavisine yönelik okula dayalı girişimler: literatür taraması Dokuz Eylül Üniversitesi Hemşirelik Yüksekokulu Elektronik Dergisi 2010; 3(3): 153160.

37. VizcainoMartinez V.,Aguilar FR., Gutierrez R.F., Martinez SM., Lopez MS., Martinez SS., Garcia EL., Artalejo FR. () Assessment of an after-school physical activity program topreventobesityamong 9-to10- year- oldchildren: a clusterrandomized trial. İnternationalJournal of Obesity 2008;32: 12-22.

38. Kropski JA, Keckley PA, Jensen GL. School-based obesity prevention programs an evidence -based review. Obesity 2008;16(5): 1009-1018 


\section{0 \\ Hergün!}
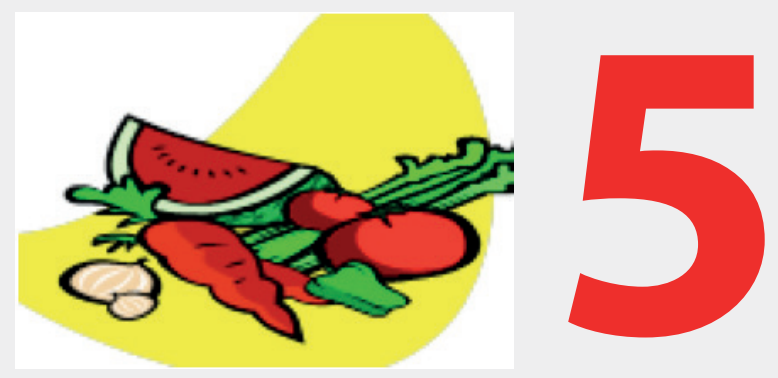

\section{YA DA DAHA FAZLA PORSIYON SEBZE VE MEYVE}

- Yeni sebze ve meyve çeşitleri dene.

- Bir ögün aile sorunudur- ögüun planlama önemli.

- Donmuş ve konserveler yerine taze besinler.
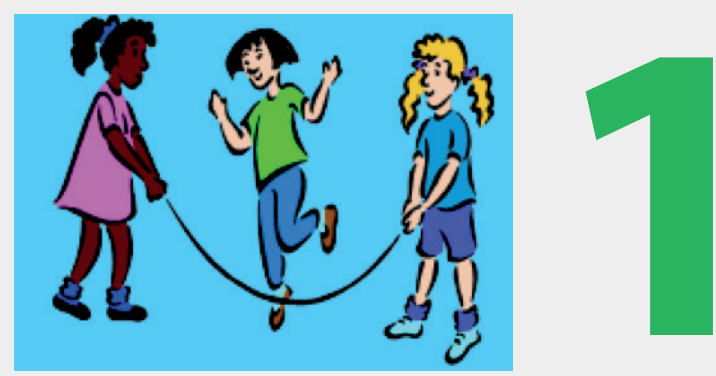

\section{SAAT TERLEYINCEYE KADAR FiZIK AKTIVITE}

- Serbest, kolay ve eğlenceli fizik aktivite yapın.

- Aile yürüyüşleri yapın.

- Müzikle dans edin

- Merdivenleri kullanın
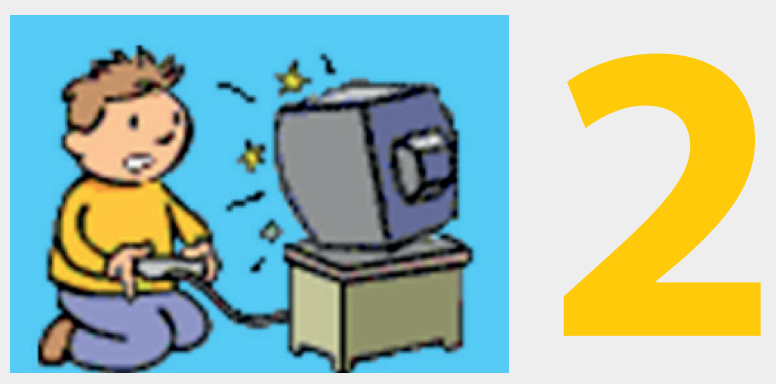

\section{SAAT ILE SINIRLI TELEVIZYON, BILGISAYAR VB}

- Bilgisayar ve televizyonu yatak odanızdan uzaklaştırın.

- 2 yaş altındaki çocuklar TV ve Bilgisayar başında zaman geçirmemeli.

- TVbaşında çok fazla zaman geçirmemek için Tv saatlerini planla.
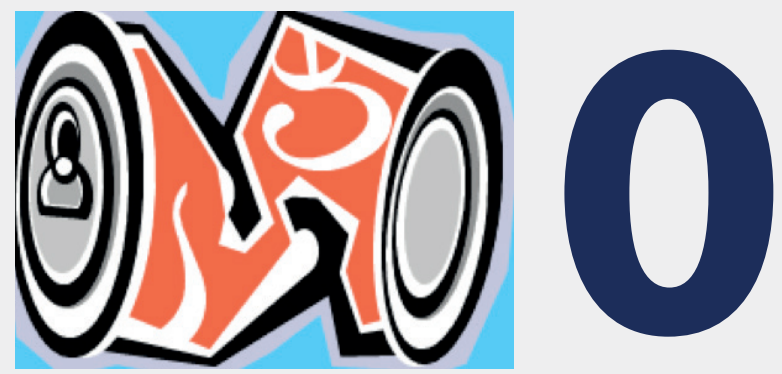

\section{O ŞEKERLI İÇECEK}

- Susadığınızda su için.

- Elinizde su şişesi taşıyın.

- \%100 Meyve suyu tüketim miktarınızı sınırlandırın. 
